\title{
Marek Barwiński
}

\section{Polityczne meandry lemkowskich cerkwi}

Zachowane do dziś łemkowskie cerkwie są jednymi z najbardziej charakterystycznych elementów krajobrazu kulturowego północnych Karpat oraz dowodem na wielonarodową i wielowyznaniową przeszłość Beskidów. Dramatyczna i skomplikowana historia oraz współczesna sytuacja tego regionu pokazuje bezpośredni wpływ wydarzeń politycznych na dzieje Łemków, ich kulturę duchową i materialną. Głównym celem artykułu jest pokazanie na przykładzie Łemkowszczyzny nadrzędnego wpływu uwarunkowań politycznych na strukturę wyznaniową. Przekształcenia i decyzje polityczne, zapadające bez udziału najbardziej zainteresowanych (w tym przypadku Łemków), skutecznie determinowały tak bardzo prywatną sferę życia jak wiara religijna. Miało to miejsce zarówno w XX w., jak i kilkaset lat wcześniej, jest tak również współcześnie.

Słowa kluczowe: Łemkowie, Łemkowszczyzna, struktura religijna, prawosławie, Kościół greckokatolicki, dziedzictwo kulturowe.

\section{Wprowadzenie}

We wczesnym średniowieczu północne Karpaty były w większości „pustką osadniczą" z nielicznymi ,wyspami” osadnictwa polskiego, słowackiego i węgierskiego, głównie w postaci grodów ulokowanych wzdłuż szlaków handlowych.

Przodkowie Łemków pojawili się w północnych Karpatach wraz z falą osadnictwa wołosko-ruskiego między XIV a XVI w. Trwająca ponad 200 lat kolonizacja wołosko-ruska posuwała się wzdłuż głównego łańcucha Karpat, z obszaru współczesnej Rumunii ku północy i zachodowi, a następnie z terenów dzisiejszej Ukrainy na zachód. W długim procesie historycznym wykształciła się grupa tzw. Rusinów karpackich, z której w kolejnych wiekach wyodrębniły się społeczności Łemków, Bojków i Hucułów. Uczestniczyli w tym zarówno polscy i słowaccy osadnicy, jak i wołoscy pasterze. Jednak zdecydowanie największe znaczenie miało osadnictwo ruskie (ukraińskie), które w XV i XVI w. zdominowało liczebnie wcześniejsze grupy etniczne, asymilując je językowo i w dużej mierze kulturowo (Reinfuss 1990). 
Do końca XVI w. powstało prawie $90 \%$ wsi, które istniały na obszarze północnych Karpat w I połowie XX w. Ukształtowała się wówczas wyraźna granica etniczna, wyznaniowa, językowa i kulturowa między Rusinami a Polakami, Słowakami i Węgrami, która istniała aż do połowy lat 40. XX w. Lemkowie zamieszkiwali zwarty obszar Beskidu Niskiego i Krynickiego, od Popradu na zachodzie aż po źródła Solinki na wschodzie. $Z$ czasem region ten po północnej stronie Karpat został nazwany Łemkowszczyzną. Był to obszar przez kilkaset lat zdominowany pod względem etnicznym przez Łemków, a nieliczna ludność polska, żydowska, słowacka i niemiecka mieszkała jedynie w kilku miastach (ryc. 1) (Reinfuss 1990, Czajkowski 1992).

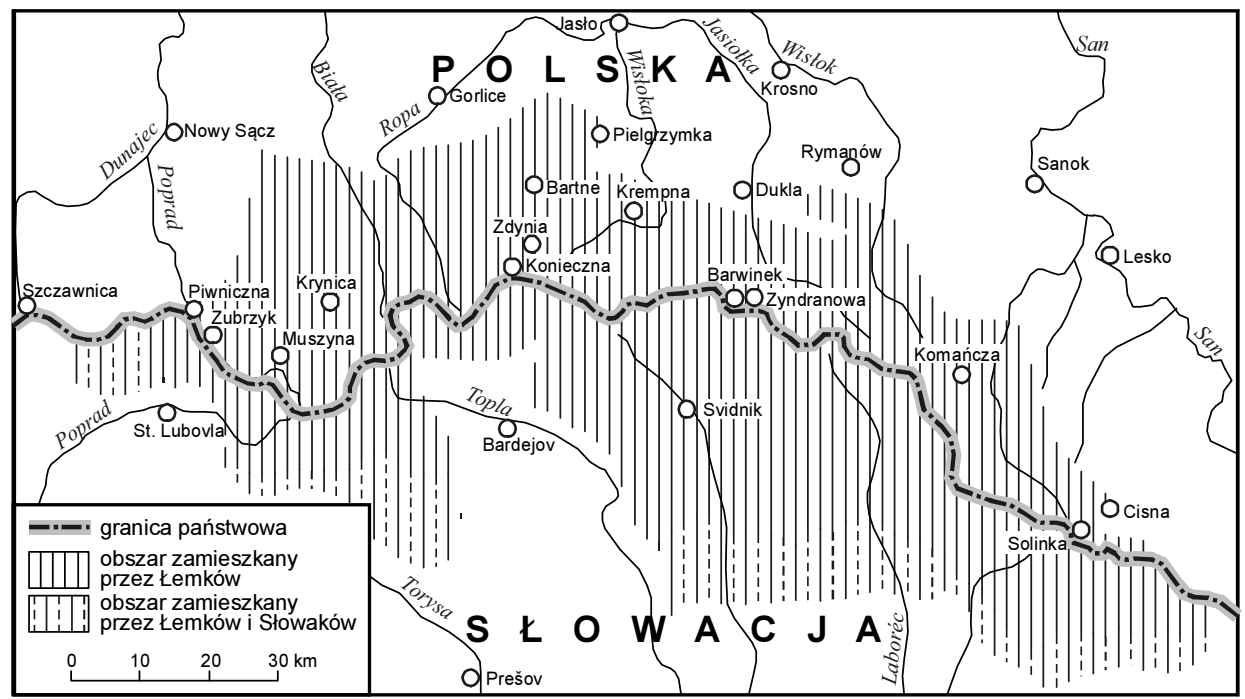

Ryc. 1. Obszar zamieszkany przez Łemków w Karpatach (stan z 1944 r.) Źródło: R. Reinfuss (1990, s. 14)

\section{Konsekwencje unii brzeskiej i rozbiorów Polski dla ludności lemkowskiej}

Zarówno pasterze wołoscy, jak i Rusini przybywający w okresie od XIV do XVI w. na obszar polskich Karpat byli wyznania prawosławnego. Często dochodziło do konfliktów pomiędzy katolicką ludnością polską a nowymi przybyszami, zwłaszcza we wsiach etnicznie mieszanych. Kościół rzymskokatolicki ostro potępiał prawosławie, a jego wyznawców traktował niemal jak pogan. Jednak w drugiej połowie XVI w. pojawiła się idea unii Kościoła katolickiego z prawosław- 
nym. Koncepcja unii miała kilka źródeł. Papież Grzegorz XIII widział w niej sojusz przeciw islamowi, a król Zygmunt III - zabezpieczenie przed wpływami moskiewskimi. Zawarcia unii pragnęło również wielu biskupów prawosławnych, ponieważ dawała im ona zrównanie w prawach i przywilejach z biskupami katolickimi.

W 1595 r. w Brześciu Litewskim, na synodzie cerkwi prawosławnej, większość biskupów prawosławnych opowiedziała się za unią z Rzymem. Na mocy unii brzeskiej Kościół prawosławny w Rzeczypospolitej uznał dogmaty katolickie i zwierzchnictwo papieża, zachował jednak wschodnie obrzędy, liturgię, hierarchię, kalendarz i prawo kanoniczne. Unia od początku nie była uznawana przez kilku biskupów prawosławnych w Polsce, a kler niższych szczebli i zwykli wierni uważali ją za zdradę prawosławia. W ten sposób ukształtowały się dwa odłamy wyznawców prawosławia na ziemiach polskich - unitów i dyzunitów. Tych pierwszych nazywano później grekokatolikami (Keller 1982, Wojewoda 1994).

Spory na tle religijnym trwały w Beskidach niemal do końca XVII w. i wygasły prawdopodobnie dopiero po 1691 r., kiedy zlikwidowano w Przemyślu biskupstwo prawosławne, a w diecezji przemyskiej - obejmującej Łemkowszczyznę - zapanował niepodzielnie katolicyzm w obrządku wschodnim. Diecezja lwowska przystąpiła do unii jeszcze później, bo w 1700 r. Jednak te dwie diecezje, które jako ostatnie zaakceptowały unię, stały się w przyszłości ostojami Kościoła greckokatolickiego (Wojewoda 1994), o czym zdecydowały rozbiory Polski. W diecezjach znajdujących się na obszarach zagarniętych przez Rosję osoby, które akceptowały warunki unii, były prześladowane, aż w końcu została ona zlikwidowana. Natomiast diecezje przemyska i lwowska weszły w skład zaboru austriackiego, w którym wyznanie greckokatolickie było oficjalnie uznawane, a nawet popierane.

W połowie XVIII w. sieć parafialna Kościoła greckokatolickiego na Łemkowszczyźnie była już w pełni ukształtowana. Cerkwie, wówczas już wyłącznie unickie, znajdowały się w większości wsi. Według spisów z drugiej połowy XVIII w. na obszarze Lemkowszczyzny funkcjonowało 139 cerkwi parafialnych i filialnych. Sieć cerkwi była najlepiej rozwinięta we wschodniej części Łemkowszczyzny, gdzie istniały one niemal w każdej wsi, a nieco słabiej - w części środkowej i zachodniej, gdzie jedna cerkiew przypadała średnio na 1,5 wsi. Pod koniec XVIII w. do typowej parafii, składającej się z jednej wsi, przynależało ok. 350 wiernych (Budzyński 1992).

Odrębny język, religia i kultura zdecydowanie odróżniały Łemków od sąsiadującej z nimi ludności polskiej. Łemkowie, choć wewnętrznie podzieleni na wiele grup lokalnych, mieli wyraźne poczucie odrębności od Polaków, które sprawiło, 
że wśród ludności łemkowskiej zaczęła się rozwijać świadomość przynależności do szerszej grupy ogólnołemkowskiej i do grupy najszerszej, narodowej.

W połowie XIX w. w Galicji Wschodniej powstała narodowa orientacja staroruska, nawiązująca do tradycji Rusi Kijowskiej, lojalna w stosunku do Austrii. W wyniku ewolucji poglądów działaczy staroruskich, w czasie Wiosny Ludów pojawiła się orientacja rusofilska, której reprezentanci podkreślali związki Rusi z Rosją, głosili ideę zjednoczenia wszystkich narodów ruskich pod panowaniem cara i propagowali prawosławie. Kierunek rusofilski objął również Łemkowszczyznę. Jego popularność wśród Lemków wiązała się m.in. z pokrewieństwem kulturowym Rusinów i Rosjan oraz wsparciem potężnego imperium carów.

W latach 60. XIX w. z ruchu staroruskiego wyodrębniła się kolejna orientacja narodowa - ukraińska. Powstała ona wśród ruskiej inteligencji we Lwowie. Orientacja ta, nawiązująca do tradycji kozackiej, akcentowała odrębność narodu ruskiego od Rosjan, uznawała jedność Rusinów galicyjskich oraz Ukrainy kijowskiej i wysuwała jako cel powstanie wolnego państwa ukraińskiego. Gdy pod koniec XIX w. popsuły się stosunki polityczne pomiędzy monarchią austro-węgierską a Rosją, Austria zaprzestała popierania orientacji staroruskiej, opowiadając się za stronnictwem ukraińskim. Hasła proukraińskie szybko opanowały wschodnią Galicję, spotykając się jednak z niechęcią na Łemkowszczyźnie. Łemkowie pozostali przy swych staroruskich i rusofilskich sympatiach. Propagandę ukraińską na Lemkowszczyźnie prowadziła głównie posłuszna dyrektywom rządu austriackiego Cerkiew greckokatolicka, co powodowało liczne konflikty między Lemkami a duchowieństwem greckokatolickim, doprowadzając nawet do odejścia części ludności łemkowskiej od Kościoła unickiego (Michna 2004, Moklak 2007, Horbal 2010). Pierwsze przypadki konwersji na prawosławie, czyli powrotu Lemków do „wiary ojców”, miały miejsce jeszcze przed I wojną światową. W 1911 r. na prawosławie przeszła znaczna część mieszkańców wsi Grab i Wyszowadka, a rok później pobliskiej Radocyny, Nieznajowej i Długiego (Krochmal 1992, Nowakowski 1992).

\section{Sytuacja polityczna i wyznaniowa na Łemkowszczyźnie w okresie międzywojennym}

Pomiędzy poszczególnymi stronnictwami, głoszącymi odmienne ideologie, rozgorzała walka polityczna, toczona w atmosferze pomówień i oszczerstw. Dotyczyło to przede wszystkim inteligencji ruskiej. Dla niepiśmiennej, bardzo konserwatywnej ludności chłopskiej, żyjącej w biedzie i izolacji, przynależność narodowa nie była wówczas istotnym problemem (Michna 2004). 
W okresie międzywojennym, po umocnieniu się w Rosji władzy bolszewików, orientacja rusofilska, nawiązująca do Rosji carskiej, ewoluowała w stronę orientacji narodowo-ruskiej, podkreślającej odrębność narodową Rusinów karpackich zarówno od Rosjan, jak i od Ukraińców. Władze polskie wyraźnie wspierały ruch ruski, promowały rozwój osobnej łemkowskiej świadomości narodowej, widząc w tym możliwość osłabienia wpływów ukraińskich w Karpatach, a w dalszej perspektywie - asymilacji Łemków.

Problem wyznaniowy stał się jednym z istotniejszych na Lemkowszczyźnie. Przyczyniła się do tego polityka personalna greckokatolickiej diecezji przemyskiej, w której na miejsca starych księży, sprzyjających nurtowi rusofilskiemu, przysyłano młodych proboszczów, zdeklarowanych Ukraińców, zaś wyświęcanych Łemków wysyłano na wschód, na tereny etnicznie ukraińskie. Młodzi greckokatoliccy księża ukraińscy stawali się coraz aktywniejsi politycznie, wzmagali propagandę skierowaną przeciw orientacji staroruskiej. Działalność polityczna nie przysparzała im popularności.

Propaganda proukraińska, szerzona $\mathrm{w}$ cerkwiach, oraz konflikty na tle materialnym pomiędzy klerem greckokatolickim a wiernymi doprowadziły do fali masowych konwersji na prawosławie w latach 1926-1932. Okres ten został później nazwany wojną religijną w górach (Krochmal 1992). Wojnę tę zapoczątkowała tzw. schizma tylawska w 1926 r. Bezpośrednią przyczyną przejścia mieszkańców Tylawy na prawosławie była zmiana w słowach liturgii, dokonana przez księdza greckokatolickiego. Zastąpił on sformułowanie $i$ wsich was, prawosławnych christijan słowami $i$ wsich was, prawowirnych christijan.

Przykład Tylawy pociągnął za sobą inne miejscowości. Silne ośrodki prawosławne powstały m.in. w Banicy, Bartnem, Florynce, Izbach, Uściu Ruskim (obecnie Uście Gorlickie). Falę tę przyspieszył brak reakcji ze strony władz kościelnych w Przemyślu i we Lwowie na protesty łemkowskich parafian przeciw postępowaniu ich duszpasterzy. Przejścia na prawosławie miały różny charakter. Były przypadki zmiany wyznania przez wszystkich mieszkańców wsi wraz z kapłanem greckokatolickim, innym razem na prawosławie przechodzili wszyscy wierni z wyjątkiem proboszcza lub część ludności opowiadała się za prawosławiem, a część za katolicyzmem. Największą falę konwersji odnotowano w latach 1926-1928. Na początku lat 30. XX w. ruch ten osłabł i około 1933 r. zanikł praktycznie całkowicie (Krochmal 1992, Nowakowski 1992).

Według zestawienia Głównego Urzędu Statystycznego, dokonanego na podstawie danych ze spisu powszechnego z 1931 r., liczba prawosławnych na badanym obszarze wynosiła 15902 osoby, co stanowiło 12,2\% ludności łemkowskiej. Należy jednak pamiętać, że wówczas proces zmian wyznania jeszcze trwał. 
Biorąc pod uwagę cały obszar zasiedlony przez Łemków, procentowo dominowali - mimo konwersji - grekokatolicy. Trudno jednoznacznie ocenić, czy podziały wśród Łemków miały bardziej charakter narodowościowy i polityczny czy wyznaniowy. Faktem jest, że obie kwestie ściśle się ze sobą łączyły. Część Łemków opowiedziała się za prawosławiem, jednak większość pozostała przy Kościele greckokatolickim, co nie oznacza, że była nastawiona proukraińsko.

We wsiach, w których zaczęła przeważać ludność prawosławna, rozpoczęły się konflikty o świątynie. Kościół greckokatolicki był prawnym właścicielem cerkwi i nie dopuszczał do nich prawosławnych, nawet wtedy, gdy cała wieś porzuciła unię. Często dochodziło do kradzieży sprzętów liturgicznych, zajmowania świątyń siłą, a nawet do rękoczynów. Zwykle kończyło się sprowadzeniem przez prawosławnych popa i budową tymczasowej cerkwi, często w bezpośrednim sąsiedztwie starszej, greckokatolickiej świątyni. Do czasów współczesnych w niektórych wsiach łemkowskich (m.in. Bartne, Bodaki) zachował się taki swoisty „dualizm cerkiewny".

W celu zahamowania przejść na prawosławie papież Pius XI utworzył dla Łemków obrządku greckokatolickiego Apostolską Administrację Łemkowszczyzny (AAŁ). Powstała ona przez wydzielenie dziewięciu dekanatów z greckokatolickiej diecezji przemyskiej i poddanie ich bezpośrednio pod władzę Watykanu. Głównymi zwolennikami powstania AAŁ byli Łemkowie rusofile. Uznawali oni to za jedyne rozwiązanie, które w radykalny sposób odcięłoby Łemków od propagandy ukraińskich ośrodków politycznych i kościelnych w Przemyślu oraz we Lwowie. Bardzo zbliżonymi motywami kierował się polski rząd, któremu również zależało na odizolowaniu Łemków od wpływów ukraińskich. Z kolei powstanie AAŁ wywołało protesty środowisk ukraińskich (Krochmal 1992, Nowakowski 1992, Prach 1992).

Utworzenie AAŁ nie usatysfakcjonowało w pełni żadnej ze stron. Trudno jednoznacznie ocenić, czy zahamowało ono proces konwersji na prawosławie. Pewne jest, że w czasie istnienia AAŁ nie zanotowano grupowych odstępstw od Kościoła katolickiego na rzecz Cerkwi prawosławnej, ale faktem jest również, że ostatnie parafie przeszły na prawosławie w 1932 r., czyli dwa lata przed utworzeniem AAŁ. Nieliczne późniejsze konwersje miały charakter indywidualny.

W przededniu wybuchu II wojny światowej Łemkowszczyzna pod względem wyznaniowym była zdecydowanie greckokatolicka. Prawosławni - mimo burzliwego okresu odchodzenia od unii w latach 1926-1932 - stanowili zaledwie ok. 12\% ogółu ludności łemkowskiej. Poza tymi dwoma głównymi wyznaniami Łemkowie należeli do różnych sekt, z których najliczniejsi byli baptyści i Badacze Pisma Świętego. Sekty religijne powstawały na Lemkowszczyźnie w okresie mię- 
dzywojennym pod wpływem emigracji łemkowskiej ze Stanów Zjednoczonych i Kanady. Były one jednak zjawiskiem marginalnym (Krochmal 1992, Nowakowski 1992).

Wskutek II wojny światowej nie zaszły istotne zmiany narodowościowe i wyznaniowe na Łemkowszczyźnie, a najtragiczniejsze dla Łemków wydarzenia nastąpily, paradoksalnie, już po wyzwoleniu tego obszaru spod okupacji niemieckiej, w latach 1944-1947.

\section{Zmiany struktury etnicznej i wyznaniowej Lemkowszczyzny w latach 1944-1989}

Władze komunistyczne, zamierzając przekształcić Polskę w państwo jednonarodowe, pod koniec II wojny postanowiły pozbyć się z nowego terytorium Polski wszelkich mniejszości narodowych, a zwłaszcza niemieckiej i ukraińskiej. W tym okresie polskie władze traktowały Ukraińców i Łemków jako jedną grupę, dlatego też wszystkie restrykcje komunistów, stosowane wobec Ukraińców, dotykały także Łemków. Było to wyraźne odejście od polityki władz II Rzeczypospolitej.

Masowe przesiedlenie Ukraińców i Łemków na terytorium radzieckiej Ukrainy w latach 1944-1946 przyniosło przełomową zmianę położenia etnicznego, politycznego i terytorialnego tych nacji. Objęło kilkakrotnie więcej osób niż późniejsza akcja „Wisła”, doprowadziło do usunięcia kilkuset tysięcy Ukraińców i Łemków nie tylko z ich ziem etnicznych, ale także z terytorium państwa polskiego. Rok później polskie władze - korzystając ze stalinowskich wzorców „rozwiązywania" problemów narodowościowych za pomocą zasady zbiorowej odpowiedzialności i przymusowych przesiedleń całych narodowości - przeprowadziły wojskową operację „Wisła”, czyli przymusowe przesiedlenie wszystkich pozostałych w Polsce Ukraińców i Łemków na obszar tzw. ziem odzyskanych (Barwiński 2013).

Wysiedlenia z lat 1944-1947 nieodwracalnie zniszczyły specyficzną strukturę narodowościową, wyznaniową i kulturową Łemkowszczyzny. Nastąpiła całkowita zmiana stosunków etnicznych i religijnych, które na tym obszarze pozostawały niezmienne od kilkuset lat. Przestały istnieć wszystkie parafie greckokatolickie i prawosławne. Spalono, rozebrano lub zdewastowano dziesiątki zabytkowych drewnianych cerkwi, przydrożnych kapliczek i cmentarzy. Reszty dokonały warunki przyrodnicze i upływ czasu. Zniszczeniu uległa zarówno kultura materialna, jak i duchowa Łemków.

W marcu 1946 r., na tzw. soborze lwowskim, władze ZSRR wymusiły na duchowieństwie greckokatolickim decyzję o zniesieniu unii brzeskiej i połączeniu 
Kościoła unickiego z Rosyjskim Autokefalicznym Kościołem Prawosławnym. Decyzja ta dotyczyła tylko ziem po stronie radzieckiej. Jednak w ówczesnych realiach politycznych było to dla polskich władz komunistycznych nakazem rozwiązania kwestii Kościoła unickiego w Polsce. W odróżnieniu od sytuacji w ZSRR w Polsce nie starano się nadać likwidacji Kościoła greckokatolickiego form prawnych. Władze polskie uznały, że po przesiedleniu większości Ukraińców i Łemków na Ukrainę w Polsce nie ma już praktycznie ani wyznawców, ani też struktur i hierarchii obrządku greckokatolickiego. Wbrew faktom i obowiązującemu stanowi prawnemu diecezje, parafie i domy zakonne uległy likwidacji. Większość duchownych wraz z biskupami została wysiedlona do ZSRR. W 1949 r., na mocy dekretu, Skarb Państwa przejął mienie Kościoła greckokatolickiego (ryc. 2). Po kilku latach majątek ten przeszedł na własność Kościoła rzymskokatolickiego, częściowo także został przekazany Polskiemu Autokefalicznemu Kościołowi Prawosławnemu, jednak nadal dużą częścią wspomnianego mienia zarządzało państwo. Grekokatolików zmuszono do nielegalnego i okazjonalnego wykonywania praktyk religijnych w prywatnych pomieszczeniach lub z konieczności w świątyniach rzymskokatolickich (Pudło 1992, Wojewoda 1994, Drozd, Halczak 2010).

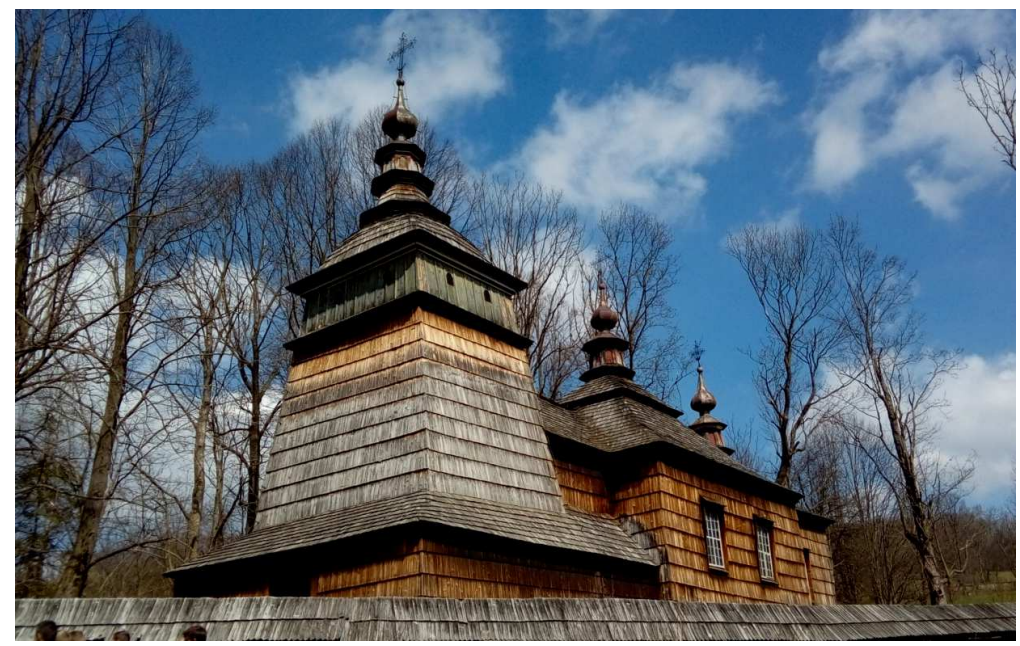

Ryc. 2. Dawna cerkiew greckokatolicka w Bartnem, obecnie muzeum Źródło: fot. M. Barwiński

Z kolei Łemkowie wyznania prawosławnego niemal od początku przesiedlenia na ziemie zachodniej i północnej Polski mogli zaspokajać swoje potrzeby religijne jawnie, chociaż w stopniu z pewnością niezadowalającym ze względu na niewielką 
liczbę i nieregularne rozmieszczenie parafii prawosławnych, które zaczęły powstawać już od 1946 r. Miały one objąć opieką duszpasterską przesiedleńców. Obrządek ten był przez rządzących traktowany zupełnie inaczej niż greckokatolicki, nie utożsamiono go z ukraińską tradycją i świadomością narodową, dlatego też władze komunistyczne sprzyjały powstawaniu cerkwi prawosławnych, zwłaszcza w skupiskach grekokatolików.

W przypadku wiernych Kościoła greckokatolickiego, czyli zdecydowanej większości Łemków, jawne zaspokajanie potrzeb religijnych w powojennej Polsce było przez kilkadziesiąt lat bardzo utrudnione lub praktycznie niemożliwe. Zostali zmuszeni do nielegalnego i okazjonalnego celebrowania praktyk religijnych w prywatnych pomieszczeniach lub z konieczności w świątyniach rzymskokatolickich. Stanęli wobec dylematu: uczęszczać na nabożeństwa łacińskie czy przejść na prawosławie i w ten sposób dochować wierności obrządkowi wschodniemu, bez możliwości przynależenia do Kościoła greckokatolickiego. Zdecydowana większość wybrała prawosławie. Formalna przynależność administracyjna miała mniejsze znaczenie niż liturgia i obrządek wschodni. Równie ważną przyczyną konwersji na prawosławie była obawa przed polonizacją, ściśle związaną z katolicyzmem. Ponadto w latach 1947-1952 Cerkiew prawosławna była jedyną instytucją wspierającą Ukraińców i Łemków (Pactwa 1992, Dudra 2004, Michna 2004, Drozd, Halczak 2010, Halczak 2015).

Grekokatolicy przetrwali, mimo że do roku 1956 nie mieli praktycznie możliwości działania. Od soboru watykańskiego II Kościół unicki, działający jawnie jedynie na emigracji, przyjął nazwę Ukraińskiego Kościoła Katolickiego, a następnie w 1975 r. - Kościoła katolickiego obrządku bizantyjsko-ukraińskiego. Potocznie nadal stosuje się tradycyjne określenia - Kościół unicki lub greckokatolicki. Polskie władze komunistyczne nie pozwalały na wybranie biskupa dla grekokatolików, dlatego zwierzchnikiem unitów papież ustanowił prymasa Polski. Po 1956 r. zezwolono na działalność parafii greckokatolickich w ramach struktur organizacyjnych Kościoła rzymskokatolickiego. Grekokatolicy zostali uznani przez władze polskie de facto, ale nadal nie de iure. Ten brak samodzielności pod względem prawnym utrzymywał się aż do 1991 r., powodując dość niejasną sytuację Kościoła unickiego, będącego jedynym dużym związkiem wyznaniowym, który nie doczekał się rejestracji przez władze PRL (Pactwa 1992).

Odradzanie się Kościoła greckokatolickiego od II połowy lat 50. XX w. miało miejsce głównie na terenach północnej i zachodniej Polski. Cerkwie pozostawione w Beskidach nadal były pozbawione opieki, a ich los zależał głównie od postawy Kościoła rzymskokatolickiego, lokalnych władz oraz nowych, polskich mieszkańców poszczególnych wsi. Najczęściej budynki cerkiewne były przejmo- 
wane przez państwo lub przez Kościół rzymskokatolicki. Obie te sytuacje były bardzo negatywnie odbierane przez ludność ukraińską i łemkowską (Drozd 2015).

Samowolne przejmowanie cerkwi łemkowskich przez Kościół rzymskokatolicki rozpoczęło się już na początku lat 50. XX w. w diecezji tarnowskiej, zwłaszcza w miejscowościach, w których osiedlili się Polacy. Na zachodniej Łemkowszczyźnie erygowano wówczas ponad 20 parafii rzymskokatolickich, do których przyłączano cerkwie jako kościoły pomocnicze. Łemkowie traktowali to jako przywłaszczenie, wręcz kradzież, nie biorąc pod uwagę faktu, iż dzięki temu świątynie miały ponownie gospodarza, który użytkował je i jednocześnie chronił przed dewastacją i zniszczeniem. Na wschodniej Łemkowszczyźnie sieć parafii rzymskokatolickich była zdecydowanie uboższa, wielu cerkwi nie zdołał przejąć Kościół rzymskokatolicki, a pozostawione „opiece” władz i lokalnej ludności, popadły w ruinę. Wielokrotnie władze państwowe, nie chcąc dopuścić do przejęcia grekokatolickiej świątyni przez Kościół rzymskokatolicki, podejmowały decyzję o jej rozbiórce. Często też zamieniano zabytkowe cerkwie na budynki gospodarcze, magazyny, czy nawet zagrody dla owiec, co w końcu prowadziło do ich dewastacji.

Oczywiście nie zawsze przejęcie cerkwi przez Kościół rzymskokatolicki chroniło ją przed zniszczeniem. Ponadto $\mathrm{z}$ reguły bezpośrednio wiązało się $\mathrm{z}$ dokonaniem zmian w wystroju. Najczęściej rozbierano lub zasłaniano ikonostas, usuwano ikony i napisy cyrylicą, zmieniano krzyże, czyli starano się zlikwidować wszelkie ślady świadczące o wschodnim dziedzictwie kulturowym świątyni (Drozd 2015).

Przejmowanie majątku greckokatolickiego przez państwo oraz Kościół rzymskokatolicki od początku wywoływało konflikty, a sytuacja uległa zaostrzeniu po roku 1956. Głównymi powodami były: powroty w Beskidy części wysiedlonych rodzin łemkowskich, domagających się nabożeństw we własnych cerkwiach i w greckokatolickim obrządku, oraz coraz większa aktywność duchowieństwa greckokatolickiego i Kościoła prawosławnego, który potrzebował łemkowskich cerkwi do rozbudowy sieci własnych parafii.

$\mathrm{Z}$ uwagi na to, iż duchowni grekokatoliccy mogli rozpocząć działalność duszpasterską na Łemkowszczyźnie, korzystając ze wsparcia struktur Kościoła rzymskokatolickiego, głównego wroga ideologicznego ówczesnych władz, zdecydowały się one wybrać mniejsze zło, czyli wydać zgodę na erygowanie parafii prawosławnych w Beskidach, a w konsekwencji doprowadzić do przejścia części grekokatolików do Kościoła prawosławnego. Dla cerkwi (jako budynków) było to wówczas najlepsze rozwiązanie, ponieważ chroniło je przed dewastacją oraz nie wiązało się ze zmianą wystroju wewnętrznego, a co za tym idzie - pozwalało zachować ich wschodni charakter. W latach 1958-1959 wzniesiono aż 14 świątyń 
prawosławnych na Łemkowszczyźnie, m.in. w Bartnem, Bodakach, Blechnarce, Hańczowej, Wołowcu, Koniecznej, Kunkowej, Morochowie, Bielance. Niektóre z tych cerkwi należały do Kościoła prawosławnego już w okresie międzywojennym (Dudra 2014, Drozd 2015).

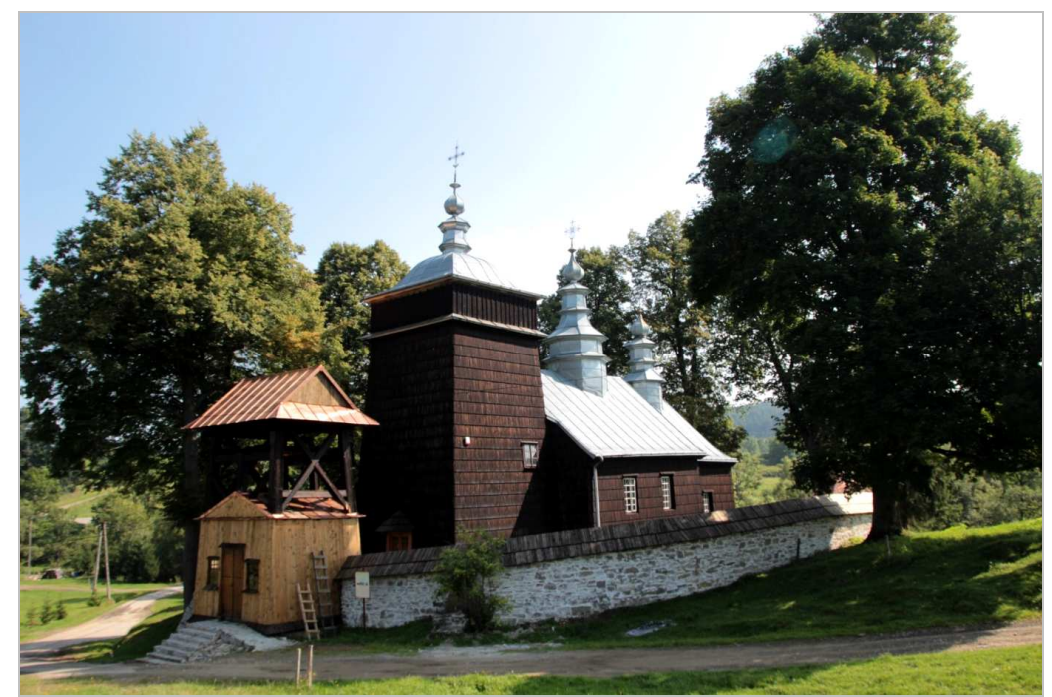

Ryc. 3. Dawna cerkiew greckokatolicka w Zdyni, obecnie cerkiew prawosławna Źródło: fot. M. Barwiński

Umacnianie się Kościoła prawosławnego w Beskidach wywołało reakcję zarówno Kościoła rzymskokatolickiego, jak i duchowieństwa greckokatolickiego, obawiających się utraty wiernych, a zwłaszcza zmniejszenia stanu posiadania w całym regionie południowo-wschodniej Polski. Oba obrządki katolickie starały się zapobiec rozwojowi prawosławia, co m.in. powodowało bardzo stanowcze działania władz państwowych, wspierających Kościół prawosławny. Efektem było przekazanie prawosławnym kolejnych cerkwi greckokatolickich, m.in. w Komańczy, Polanach, Pielgrzymce, Gładyszowie, Turzańsku, Szczawnem, Zdyni (ryc. 3), co doprowadziło do konfliktu z katolikami obu obrządków (Drozd 2015). Jednak nie zawsze władze pozytywnie reagowały na postulaty hierarchów i wiernych prawosławnych. Znane są liczne przypadki administracyjnego utrudniania lub spowalniania przekazywania cerkwi czy erygowania nowych parafii, m.in. w Rozdzielu, Olchowcu, Śnietnicy, Krempnej, Tylawie. Jako podstawowy argument władze podawały niewielką liczbę wiernych. Przekazywane cerkwie były także w bardzo złym stanie technicznym, zniszczone lub wręcz zdewastowane, głównie 
poprzez wcześniejsze użytkowanie ich jako magazynów lub obór dla zwierząt (Dudra 2014).

W latach 60. XX w. władze administracyjne, zarówno centralne, jak i lokalne, z jednej strony, obawiając się odrodzenia Kościoła greckokatolickiego w Beskidach, nalegały na zwiększenie aktywności duchowieństwa prawosławnego, zaś z drugiej strony, metodami ekonomicznymi i prawnymi, utrudniały mu prowadzenie działalności duszpasterskiej. W urzędowych sprawozdaniach podkreślano „grekokatolizację prawosławia”, notowano przypadki przechodzenia parafii prawosławnych na wschodni obrządek katolicki, podkreślano pasywność i gorsze przygotowanie duszpasterskie i teologiczne duchownych prawosławnych (Dudra 2014). Mimo to przez cały okres PRL stosunek władz do Kościoła prawosławnego był zdecydowanie przychylniejszy niż do Kościoła greckokatolickiego.

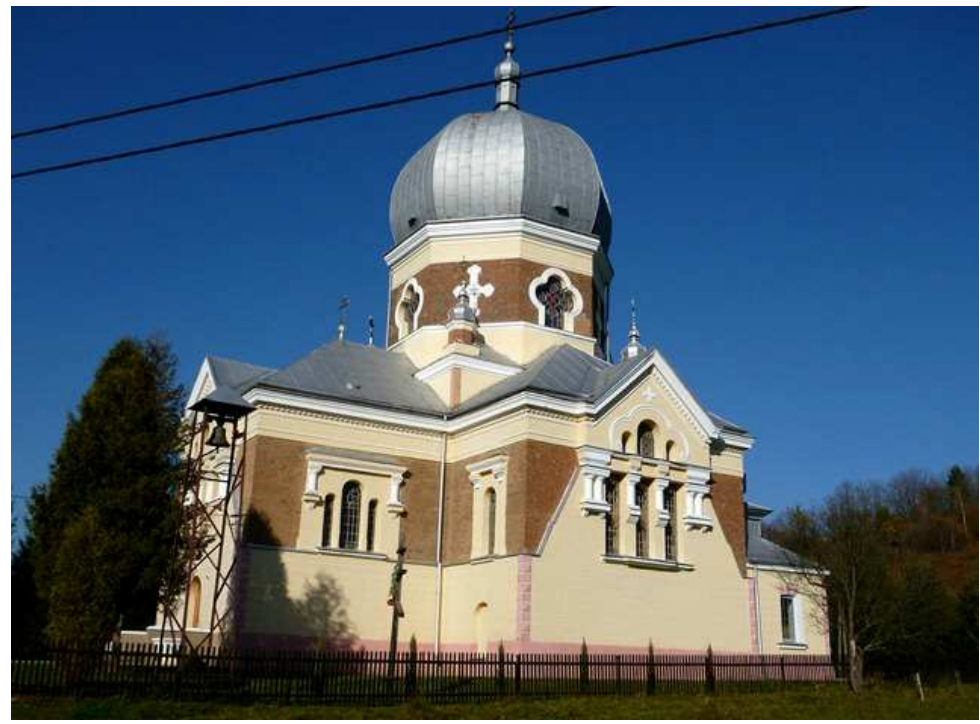

Ryc. 4. Dawna cerkiew greckokatolicka w Polanach, obecnie kościół rzymskokatolicki Źródło: fot. M. Barwiński

Użytkowanie dawnych cerkwi greckokatolickich przez Kościół rzymskokatolicki lub prawosławny było w latach 50. i 60 . XX w. najboleśniejszą kwestią dla powracających w rodzinne Beskidy Łemków. Brak świątyń do odprawiania nabożeństw zgodnych z wyznawanym obrządkiem doprowadził do licznych lokalnych konfliktów. Najpoważniejsze z nich miały miejsce w Polanach, Komańczy i Gładyszowie. 
Greckokatolicka cerkiew w Polanach (gmina Krempna) jest nietypowa jak na Łemkowszczyznę - zbudowana na początku XX w. na planie krzyża greckiego, murowana, z jedną centralną kopułą (ryc. 4). W 1944 r., podczas walk o Przełęcz Dukielską, została częściowo zburzona. W 1949 r. cerkiew przekazano Kościołowi rzymskokatolickiemu. Nie przeprowadzono jednak jej odbudowy, a nabożeństwa łacińskie początkowo odprawiano w domach prywatnych, a od $1962 \mathrm{r}$. w nowo wybudowanej drewnianej kaplicy. Cerkiew popadała w ruinę. W roku 1960 gospodarz z Polan, Jan Gałczyk, zapoczątkował starania o odbudowę cerkwi. Rozpoczęła się wówczas trwająca do początku XXI w. „wojna religijna” w Polanach. Ponieważ władze nie chciały zgodzić się na reaktywowanie parafii greckokatolickiej, zaczęto zbierać podpisy pod podaniem o odbudowę cerkwi prawosławnej, mimo że łemkowscy mieszkańcy Polan w zdecydowanej większości byli grekokatolikami. W 1966 r. władze wojewódzkie zgodziły się na utworzenie tam parafii prawosławnej i przekazały jej cerkiew, oczywiście bez zgody Kościoła katolickiego. Świątynię odbudowano w latach 1965-1971, głównie dzięki pomocy finansowej łemkowskich emigrantów z USA. W trakcie remontu rozebrano drewnianą kaplicę rzymskokatolicką. W listopadzie 1971 r. rzymscy katolicy pod przywództwem miejscowego proboszcza wyłamali zamki i zajęli odnowioną cerkiew. Proboszcz ogłosił likwidację parafii prawosławnej. Cerkiew przemianowano na kościół pod wezwaniem Matki Boskiej Częstochowskiej. Zniszczono ikonostas, ołtarz, zabrano sprzęty liturgiczne. Z krzyży na cerkwi i na cmentarnych nagrobkach odcięto drugie ramiona i poprzeczki. Ocalał jedynie górujący nad wsią prawosławny krzyż na głównej kopule cerkwi, ponieważ dostęp do niego był utrudniony. Przez kilka lat liturgię prawosławną odprawiano na placu przy cerkwi. Sprawa trafiła do sądu, który w 1982 r. orzekł, że obie strony mają wspólnie użytkować cerkiew, jednak nigdy do tego nie doszło. W wyniku apelacji wyrok sądu zmieniono i orzeczono prawo Kościoła rzymskokatolickiego do wyłącznego użytkowania świątyni. Po odwołaniu proboszcza i reaktywowaniu w 1991 r. przez papieża Jana Pawła II greckokatolickiej diecezji przemyskiej, Łemkowie z Polan (w zdecydowanej większości grekokatolicy) zorganizowali referendum, w którym większość mieszkańców wsi - w tym wielu Polaków - opowiedziała się za wspólnym użytkowaniem cerkwi przez katolików obu wyznań. Od 1992 r. świątynia w Polanach pełni funkcję zarówno rzymskokatolickiego kościoła parafialnego, jak i cerkwi filialnej greckokatolickiej parafii Zyndranowa. Ostatecznie spór o cerkiew został zakończony dopiero w 2003 r. formalnym zlikwidowaniem parafii prawosławnej w Polanach.

Komańcza była jedyną wsią na terenie Beskidu Niskiego, w której po zakończeniu II wojny światowej nieprzerwanie odbywały się msze greckokatolickie. 


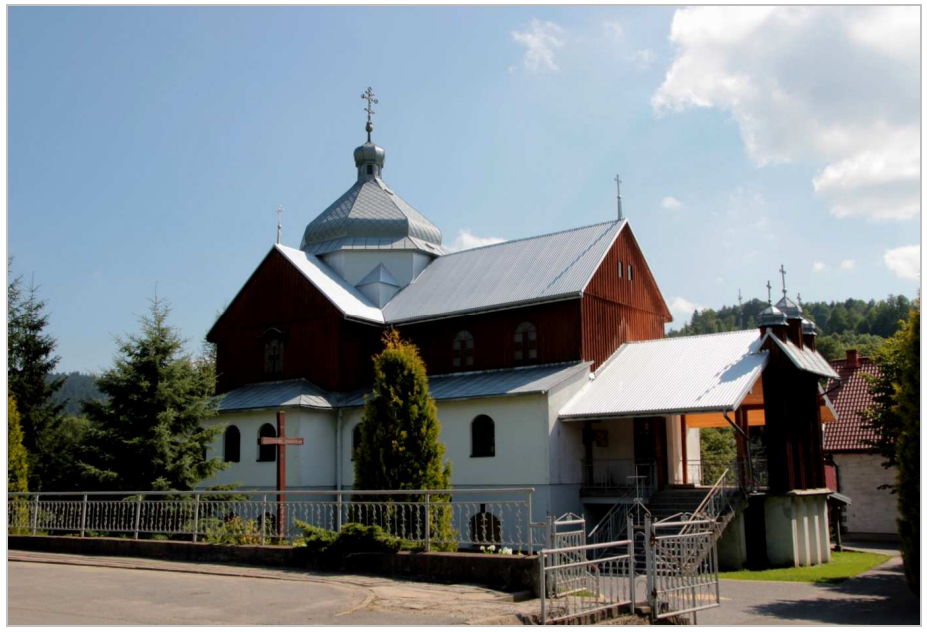

Ryc. 5. Wybudowana w latach 80 . XX w. cerkiew greckokatolicka w Komańczy Źródło: fot. M. Barwiński

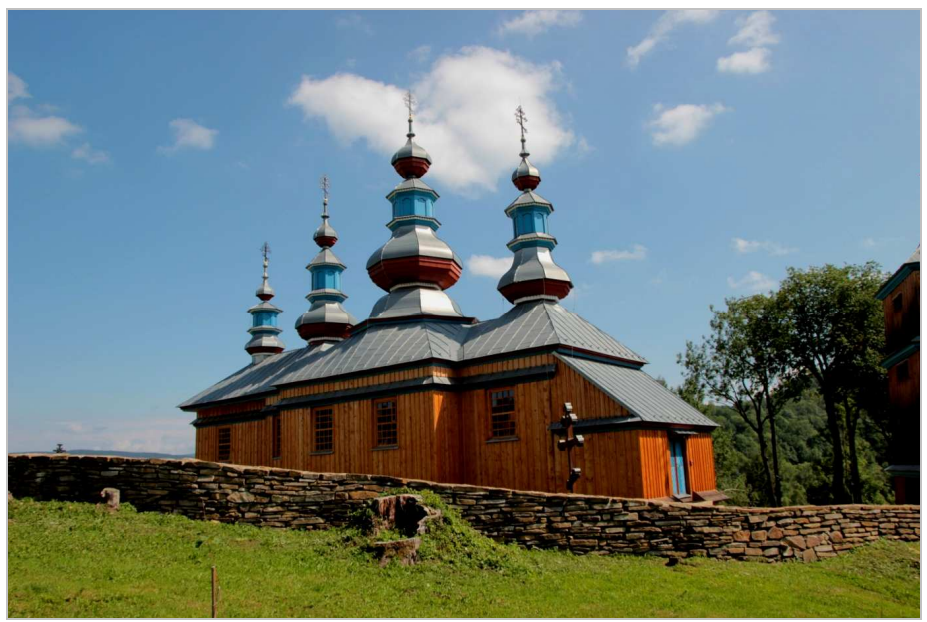

Ryc. 6. Odbudowana po pożarze z 2006 r. cerkiew prawosławna w Komańczy, dawna cerkiew greckokatolicka Źródło: fot. M. Barwiński

Początkowo grekokatolicy odprawiali nabożeństwa w swojej zabytkowej cerkwi. W lipcu 1961 r. podstępem zamknięto świątynię. Została ona zajęta przez pracowników Służby Bezpieczeństwa, którzy udając turystów, pod pozorem chęci zwiedzania cerkwi, weszli do wnętrza i zabrali księdzu klucze. Po paru miesiącach cerkiew przekazano nielicznym w Komańczy wyznawcom prawosławia. Grekoka- 
tolicy próbowali początkowo porozumieć się z prawosławnymi, nie przyniosło to jednak żadnych efektów. Nie mogąc oficjalnie wybudować nowej świątyni, przenieśli z Dudyńca koło Sanoka zniszczoną drewnianą cerkiew greckokatolicką. Odnowili ją i umieścili jako najwyższy, trzeci poziom nowej murowanej świątyni, którą otwarto w 1988 r. (ryc. 5). Zabytkowa cerkiew, przejęta przez prawosławnych, spłonęła w 2006 r., jednak została odbudowana w identycznym kształcie w roku 2010 (ryc. 6). Obecnie w niewielkiej Komańczy są trzy świątynie parafialne trzech różnych wyznań chrześcijańskich.

W Gładyszowie (gmina Uście Gorlickie) przed II wojną światową znajdowały się dwie cerkwie - obydwie greckokatolickie, w mniejszej była plebania i kaplica. Po 1947 r. większą cerkiew przejął Kościół rzymskokatolicki, a mniejszą zamieniono na stodołę. W 1957 r. ksiądz sprowadził w tajemnicy duchownego unickiego, aby w cerkwi odprawiał nabożeństwa dla powracających z wysiedlenia Łemków. Po kilku latach duchowny został wydalony przez Służbę Bezpieczeństwa. W latach 1967-1968 łemkowscy mieszkańcy Gładyszowa ze względu na niemożność uczestniczenia w mszach greckokatolickich sprowadzili księdza prawosławnego. Polscy mieszkańcy wsi nie pozwolili odprawiać nabożeństw prawosławnych w dużej cerkwi, pełniącej funkcję świątyni rzymskokatolickiej, dlatego też Łemkowie wyremontowali zamienioną na stodołę małą cerkiew i tam uczestniczyli w mszach prawosławnych. Na początku lat 80 . władze zezwoliły na odprawianie nabożeństw greckokatolickich w dużej cerkwi, jednak większość Łemków pozostała przy wyznaniu prawosławnym. Obecnie w Gładyszowie w dużej cerkwi odbywają się msze obu obrządków katolickich (ryc. 7), a w drugiej, mniejszej - nabożeństwa prawosławne. Łemkowie w Gładyszowie, przed wysiedleniem będący wyłącznie wyznania greckokatolickiego, w wyniku procesów, które zaszły w tej społeczności w związku z niezależnymi od nich decyzjami polityczno-administracyjnymi, podejmowanymi przez ostatnie kilkadziesiąt lat, w przeważającej części deklarują się obecnie jako wyznawcy prawosławia (Barwiński 1999).

Przytoczone trzy przykłady obrazują bardzo skomplikowaną i zróżnicowaną sytuację wyznaniową na Lemkowszczyźnie w okresie PRL. Uzmysławiają, przed jakimi problemami stanęli Łemkowie po powrocie z wysiedlenia i jak trudnych wyborów byli zmuszeni dokonywać. Jednocześnie wyraźnie widać, że często decyzja tak ważna i tak osobista jak wybór wyznania była uzależniona od odgórnych ustaleń politycznych, na które najbardziej zainteresowani, czyli Łemkowie, nie mieli żadnego wpływu.

W latach 70. i 80. XX w. stan cerkwi, zwłaszcza opuszczonych lub wykorzystywanych gospodarczo, nadal się pogarszał. Typowe w tym okresie dążenie polskich władz do „moralno-politycznej jedności narodu polskiego” przejawiało się 
w dalszym zacieraniu materialnych śladów wielowiekowej obecności Ukraińców i Łemków na obszarze południowo-wschodniej Polski. Rozebrano lub zdewastowano wiele opuszczonych cerkwi, które przetrwały wojnę i pierwsze lata powojenne. Świadome rujnowanie cerkwi trwało do samego końca istnienia PRL. Po akcji „Wisła” zniszczeniu uległo wielokrotnie więcej cerkwi niż podczas wojny i przesiedleń. Dewastowano też przydrożne kapliczki i cmentarze. Podczas działań wojennych, łącznie z walkami z UPA, na Łemkowszczyźnie i w Bieszczadach zniszczono sześć cerkwi, natomiast w okresie PRL w południowo-wschodniej Polsce całkowitemu unicestwieniu w wyniku rozbiórki, pożaru, wysadzenia, dewastacji uległo ok. 300 cerkwi (Wojewoda 1994). Było to spowodowane głównie wysiedleniem Łemków i Ukraińców, zmianami prawnowłasnościowymi, niechęcią władz komunistycznych do Kościoła katolickiego (w tym także greckokatolickiego) oraz do ludności ukraińskiej i łemkowskiej, a także wrogim nastawieniem ludności polskiej do wszystkiego, co ukraińskie (Wojewoda 1994, Wysocki 2011, Drozd 2015).

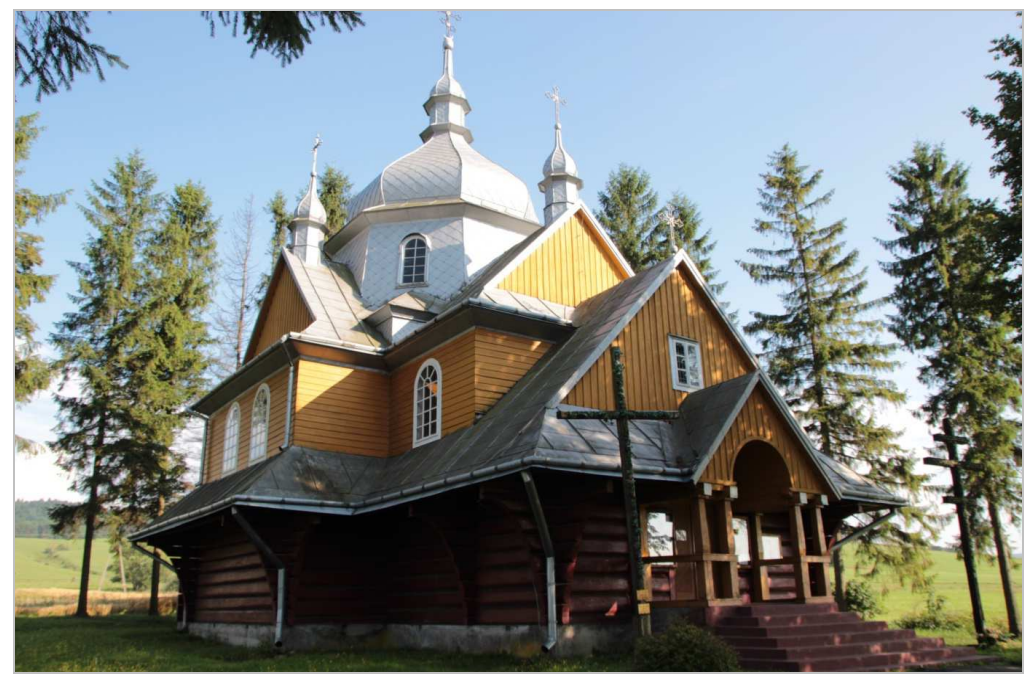

Ryc. 7. Dawna cerkiew greckokatolicka w Gładyszowie, obecnie kościół rzymskokatolicki

Źródło: fot. M. Barwiński

W latach 80. XX w. nastąpiła relatywna poprawa sytuacji grekokatolików. Co prawda, władze nadal nie zgadzały się na legalizację tego wyznania, inwigilowały duchownych oraz wspierały Kościół prawosławny w jego działalności wśród grekokatolików. Nie przeszkadzały jednak w tworzeniu kolejnych placówek, zgadzały 
się na zagraniczne pielgrzymki wiernych oraz przyjazdy dostojników hierarchii greckokatolickiej z Watykanu do Polski. Ponadto od wyboru papieża Jana Pawła II nastawienie zarówno Stolicy Apostolskiej, jak i Episkopatu Polski do dążeń grekokatolików stało się bardziej przychylne. Nie bez znaczenia były także zachodzące w drugiej połowie lat 80 . zmiany wewnętrzne w ZSRR, które m.in. przejawiały się $\mathrm{w}$ złagodzeniu polityki wobec działających tam nielegalnie struktur greckokatolickich, co z kolei rzutowało na postawę władz polskich (Drozd, Halczak 2010). Pomimo kilku pozytywnych zmian w sytuacji grekokatolików, ich podstawowe postulaty, powtarzane już od kilkudziesięciu lat, pozostawały niezrealizowane przez władze państwowe i przez Episkopat rzymskokatolicki. Kościół unicki nadal funkcjonował w Polsce w ograniczonym zakresie w ramach struktur Kościoła rzymskokatolickiego (Drozd 2010).

\section{Przekształcenia polityczne i wyznaniowe na Lemkowszczyźnie po 1989 r.}

Choć demokratyzacja życia w Polsce nie usunęła nieodwracalnych konsekwencji powojennej historii Kościoła unickiego, to jednak stworzyła zupełnie nowe możliwości dla jego funkcjonowania. W 1991 r. papież Jan Paweł II odtworzył hierarchię Kościoła greckokatolickiego, reaktywując greckokatolicką diecezję przemyską oraz diecezje na Ukrainie i powołując po raz pierwszy od pół wieku biskupa ordynariusza obrządku bizantyjsko-ukraińskiego dla diecezji przemyskiej. Zakończyło to formalnie stan zawieszenia, w którym unicka wspólnota religijna żyła w okresie powojennym (Pactwa 1992).

Przed wysiedleniem do Kościoła unickiego należało na Łemkowszczyźnie ponad 100 cerkwi. Obecnie nabożeństwa wyłącznie greckokatolickie odbywają się jedynie w dwóch świątyniach - w wybudowanej w latach 80 . XX w. cerkwi w Komańczy oraz - od czasu kiedy wybudowano w tej wsi nowy kościół rzymskokatolicki - w starej cerkwi w Rzepedzi (gmina Komańcza). Wspólne użytkowanie cerkwi przez Kościół rzymskokatolicki i greckokatolicki na obszarze Łemkowszczyzny ma miejsce od lat 80. XX w. w Losiu, Olchowcu, Gładyszowie, Polanach, Krynicy, Zyndranowej, Rozdzielu, Uściu Gorlickim, Nowicy, Pętnej, a od początku lat 90. także w Bielance, Przysłupie, Małastowie, Grabiu. Z kolei w wielu zabytkowych cerkwiach łemkowskich odbywają się wyłącznie nabożeństwa rzymskokatolickie, pomimo zamieszkiwania w tych wsiach - obok ludności polskiej - również Łemków wyznania greckokatolickiego lub prawosławnego (ryc. 8). Sytuacja taka ma miejsce m.in w Smolniku, Radoszycach, Wisłoku 
Wielkim, Tylawie, Myscowej, Chyrowej, Krempnej, Kotaniu, Desznicy, Świątkowej Wielkiej, Owczarach, Smerekowcu.

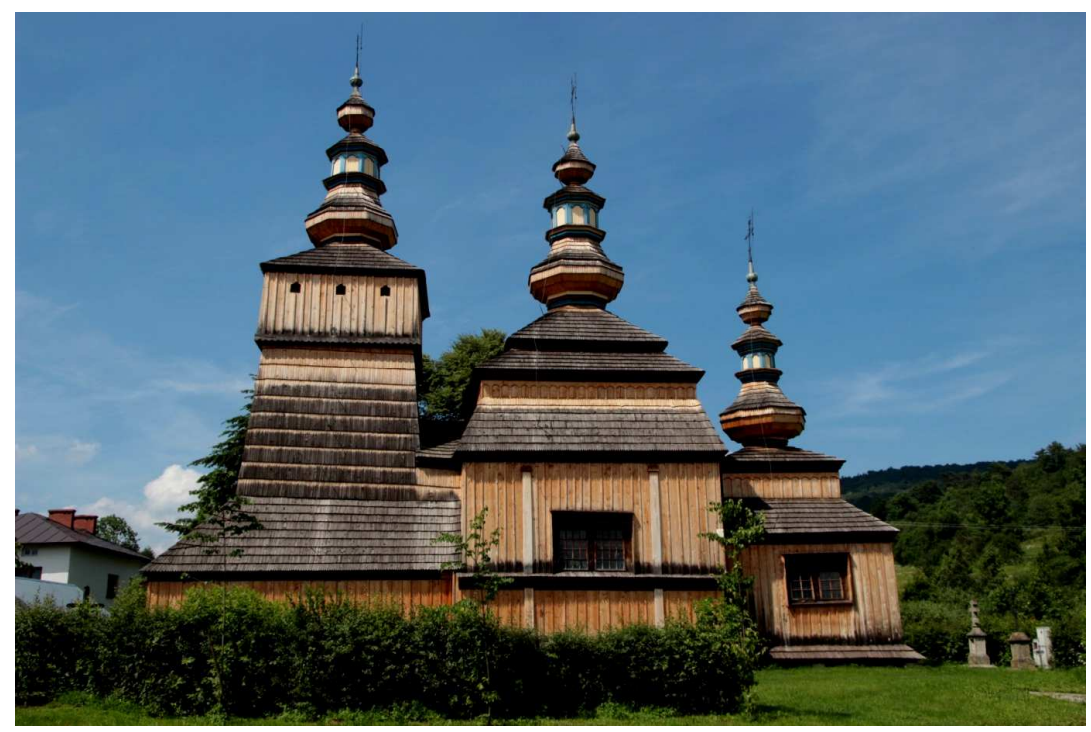

Ryc. 8. Dawna cerkiew greckokatolicka w Krempnej, obecnie kościół rzymskokatolicki

Źródło: fot. M. Barwiński

Wiele dawnych cerkwi greckokatolickich zostało w okresie PRL przejętych przez Polski Autokefaliczny Kościół Prawosławny i do dzisiaj pozostaje pod jego administracją. Są to świątynie w Komańczy, Wołowcu, Gładyszowie, Koniecznej, Kunkowej (ryc. 9), Leszczynach, Hańczowej, Wysowej, Zdyni (ryc. 3) i Blechnarce. W cerkwiach tych odbywają się wyłącznie nabożeństwa prawosławne (z wyjątkiem Zdyni, gdzie odprawia się również nabożeństwa rzymskokatolickie). Msze prawosławne są także sprawowane w cerkwiach, które już przed II wojną światową należały do Kościoła prawosławnego - w Turzańsku, Pielgrzymce, Bartnem, Bodakach - oraz w nowo wybudowanych cerkwiach w Zyndranowej, Bielance, Gorlicach i Krynicy.

Najbardziej „ekumeniczną” świątynią w Beskidach była do niedawna cerkiew w Bielance, w której od 1991 do 2014 r. odprawiano nabożeństwa wszystkich trzech głównych obrządków Łemkowszczyzny - łacińskiego, greckokatolickiego i prawosławnego. Trzy lata temu w tej miejscowości oddano do użytku nową cerkiew prawosławną, a zabytkowa świątynia ponownie stała się własnością Kościoła greckokatolickiego. 


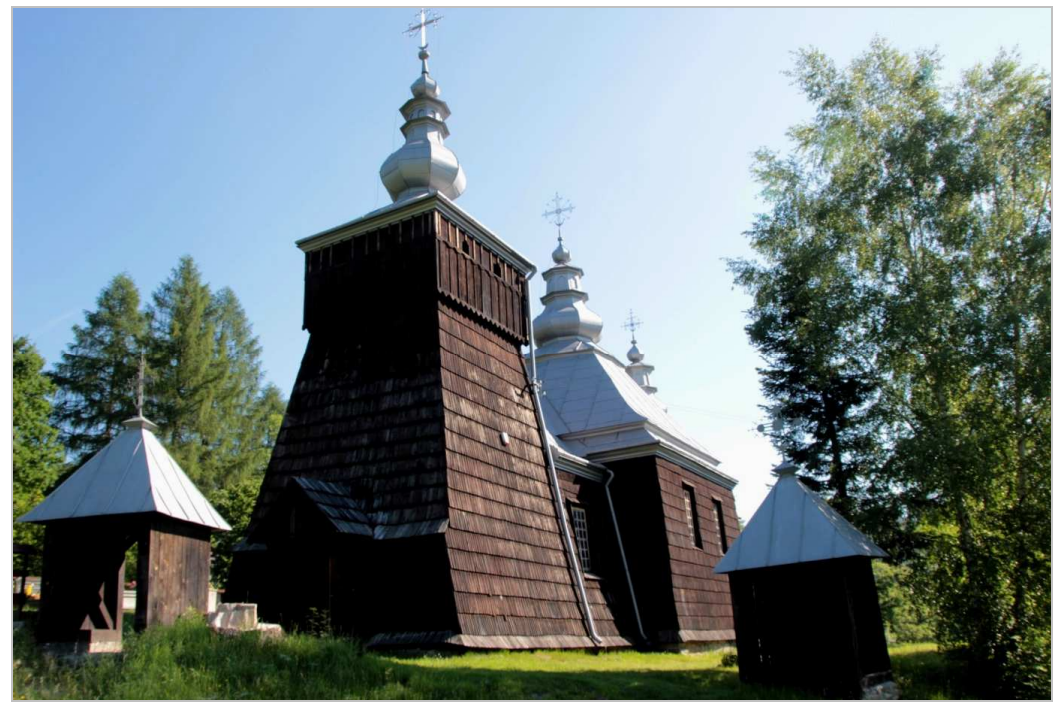

Ryc. 9. Dawna cerkiew greckokatolicka w Kunkowej, obecnie cerkiew prawosławna Źródło: fot. M. Barwiński

Od początku lat 90 . XX w. rozpoczął się nowy okres działalności cerkwi znajdujących się na Łemkowszczyźnie. Poza funkcją religijną i integracyjną dla mieszkańców wsi w coraz szerszym zakresie zaczęła rozwijać się także funkcja kulturowa i społeczna. Świątynie i plebanie obu wschodnich obrządków stały się miejscem licznych wykładów i spotkań poświęconych kulturze i historii Łemków i Łemkowszczyzny. Nastąpiło wyraźne ożywienie działalności greckokatolickiej i prawosławnej w Beskidach. Powstały liczne stowarzyszenia społeczne, kulturalne, sportowe, powiązane z poszczególnymi parafiami, organizujące zajęcia młodzieżowe, obozy, rajdy, pielgrzymki, imprezy kulturalne.

$\mathrm{Na}$ dużą skalę rozpoczęła się renowacja zabytkowych budynków cerkiewnych oraz inwentaryzacja i restauracja cmentarzy łemkowskich, także tych położonych w opuszczonych wsiach. Powstały szlaki turystyczne rozpowszechniające zabytki sakralne. W latach 2001-2003 utworzono Szlak Architektury Drewnianej w Małopolsce, obejmujący 252 zabytkowe obiekty drewniane województwa małopolskiego, w tym 49 cerkwi zachodniej Łemkowszczyzny. W 2013 r. cztery znajdujące się na tym szlaku beskidzkie cerkwie greckokatolickie (w Kwiatoniu, Powroźniku, Brunarach Wyżnych i Owczarach) zostały wpisane na listę światowego dziedzictwa kulturowego i naturalnego UNESCO (ryc. 10).

Na podobnym Szlaku Architektury Drewnianej w województwie podkarpackim znajduje się wiele cerkwi z Bieszczad, okolic Przemyśla oraz 14 z regionu 
środkowej i wschodniej Łemkowszczyzny, w tym jedna (w Turzańsku) jest wpisana na listę UNESCO. Oznacza to, że łącznie ten popularny szlak turystyczny upowszechnia i chroni 63 zabytkowe cerkwie łemkowskie, w zdecydowanej większości greckokatolickie, głównie z terenu zachodniej Łemkowszczyzny (w tym pięć łemkowskich cerkwi znajduje się pod specjalnym patronatem UNESCO), a także umożliwia ich zwiedzanie.

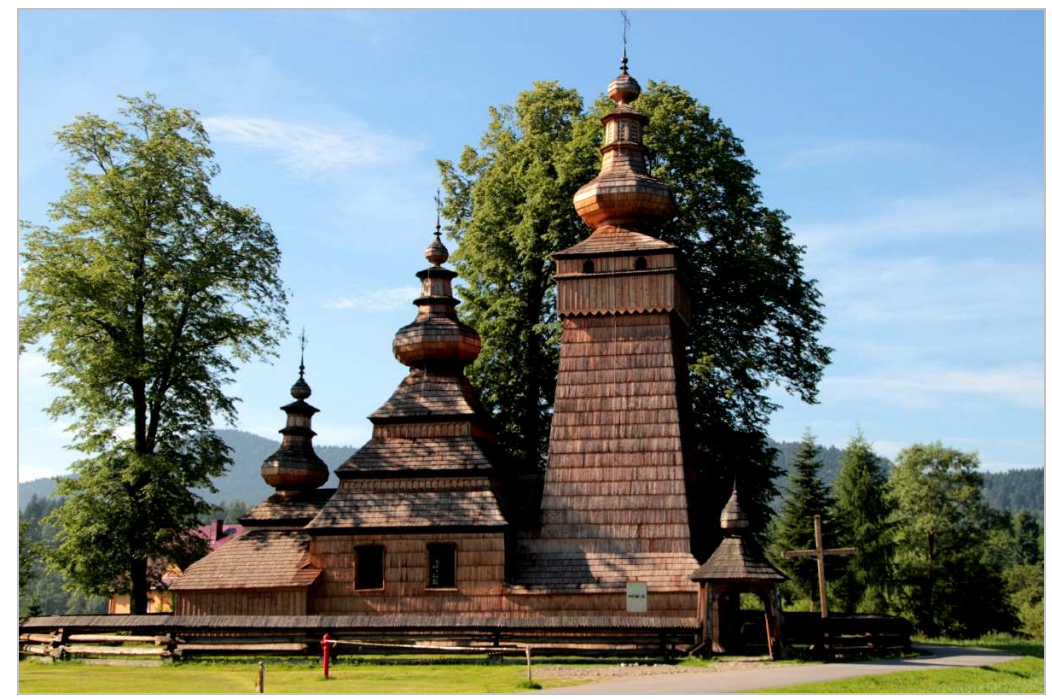

Ryc. 10. Wpisana na listę UNESCO dawna cerkiew greckokatolicka w Kwiatoniu, obecnie kościół rzymskokatolicki

Źródło: fot. M. Barwiński

Dziesiątki cerkwi na Łemkowszczyźnie nie przetrwało okresu PRL. Po większości z nich nic się nie zachowało, po części pozostały fundamenty, fragmenty ścian czy cebulastych bani oraz porzucone żeliwne krzyże. Niektóre doczekały się specyficznego upamiętnienia. W 2008 r. w Małopolsce powstał projekt „Zapomniane wsie Łemkowszczyzny". Miał on na celu ocalenie od całkowitego zapomnienia nieistniejących współcześnie wiosek w Beskidzie Niskim, m.in. Czarnego, Długiego, Lipnej, Nieznajowej, Radocyny, Świerzowej Ruskiej, z których mieszkańcy zostali wysiedleni w latach 1945-1947. Głównym elementem tego projektu są symboliczne drewniane „drzwi do wsi”, ustawione na łące, na skraju pola, w miejscu gdzie kiedyś zaczynała się wieś (ryc. 11). Są one swoistym monumentem symbolizującym nieistniejące wsie, po których dzisiaj pozostały jedynie zdziczałe sady, cmentarze, krzyże i kapliczki oraz miejsce, w którym kiedyś stała cerkiew (ryc. 12). Na tablicach informacyjnych, umieszczonych na drzwiach, 
znajdziemy rys historyczny danej wsi, mapki z zaznaczą lokalizacją cerkwi i dawnych gospodarstw oraz nazwiska mieszkańców. Drzwi te są symbolami toczącego się tutaj dawniej życia.

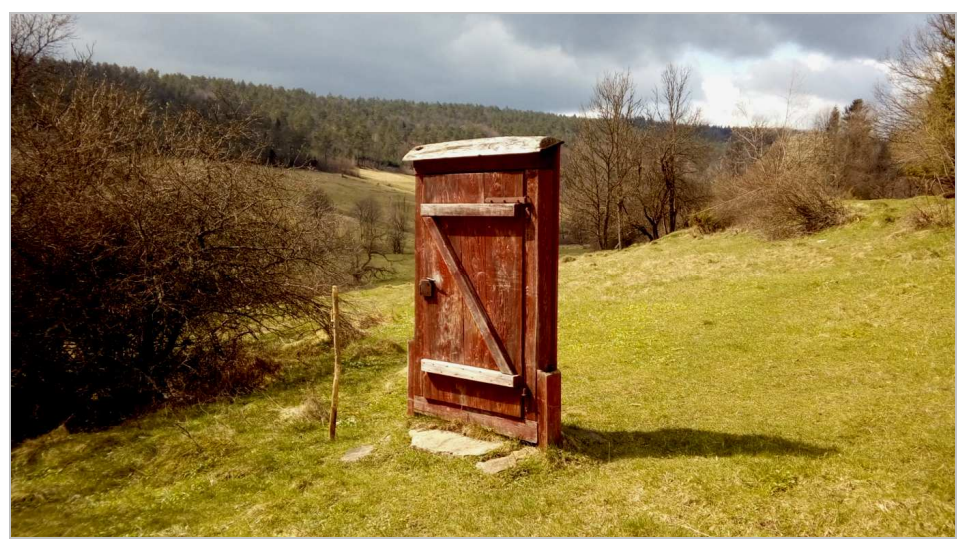

Ryc. 11. „Drzwi do wsi”, część projektu „Zapomniane wsie Łemkowszczyzny”; Czarne Źródło: fot. M. Barwiński

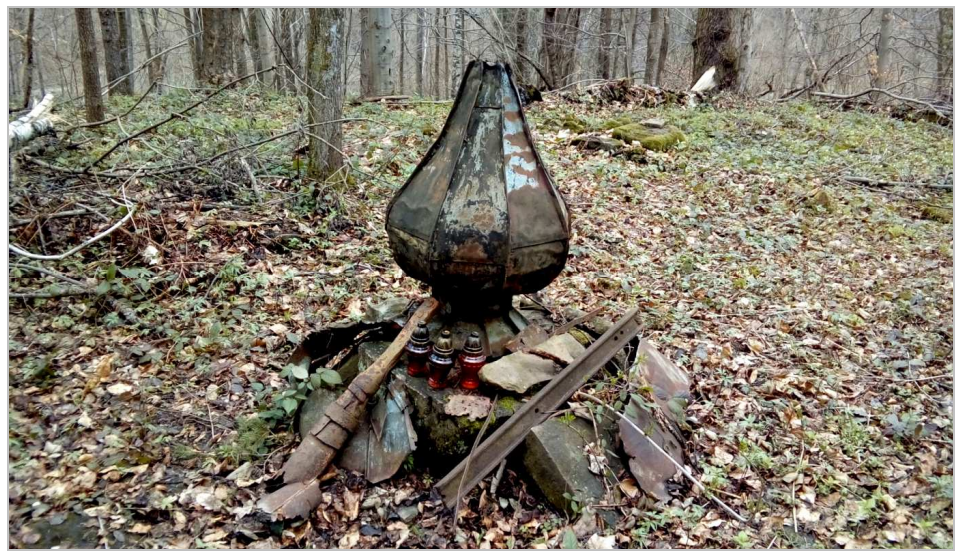

Ryc. 12. Pozostałości po zniszczonej cerkwi greckokatolickiej w Świerzowej Ruskiej Źródło: fot. M. Barwiński

W strukturze wyznaniowej współczesnej Łemkowszczyzny przeważają oczywiście wyznawcy Kościoła rzymskokatolickiego, co jest konsekwencją wysiedlenia rodzimej ludności łemkowskiej i napływu katolickiej ludności polskiej, która stanowi dzisiaj zdecydowanie dominującą grupę narodowościową w Beskidach. 
Wśród Łemków mieszkających w Beskidach, podobnie jak przed II wojną światową, są zarówno grekokatolicy, jak i prawosławni. Jest jednak istotna różnica: w 1939 r. wśród Łemków najwięcej było grekokatolików - stanowili oni ok. 86-88\% ogółu tej społeczności, natomiast obecnie wyznawcy obu obrządków chrześcijańskich, według różnych szacunków, tworzą w Beskidach społeczności o zbliżonej liczbie członków. Głównym powodem wyraźnego wzrostu liczebności Łemków wyznania prawosławnego był brak możliwości swobodnego funkcjonowania Kościoła greckokatolickiego przez kilkadziesiąt lat. Gdyby nie polityczno-administracyjne decyzje władz PRL, dzisiejsza struktura wyznaniowa mieszkańców Łemkowszczyzny byłaby z pewnością inna.

Oczywiście jest również wielu Łemków wyznania rzymskokatolickiego, choćby dlatego, że przez kilkadziesiąt lat dla dużej grupy ludności łemkowskiej był to jedyny dostępny obrządek. Także spora część Łemków z rodzin etnicznie mieszanych, $\mathrm{z}$ biegiem czasu, uległa latynizacji.

\section{Wnioski}

Sylwetki ocalałych drewnianych cerkwi łemkowskich stanowiły w przeszłości i nadal stanowią charakterystyczny element krajobrazu - nie tylko kulturowego - Beskidów. Los tych budynków przez dziesięciolecia bardzo silnie splótł się z dziejami ludzi, którzy je wznosili i modlili się w nich - był równie zagmatwany i tragiczny. Wyznanie religijne było i nadal pozostaje dla Lemków podstawą poczucia odrębności i tożsamości, a budynki cerkiewne są najistotniejszymi symbolami ich ,prywatnej ojczyzny”.

Wszelkie zmiany struktury wyznaniowej na Łemkowszczyźnie, począwszy od XVII w., były poprzedzane istotnymi decyzjami politycznymi, a niekiedy także ewolucją poczucia tożsamości narodowej. Osiedlający się w Beskidach Wołosi i Rusini byli wyznania prawosławnego. Już w XVI w. na północnym łuku Karpat pojawiły się drewniane cerkwie. Po zawarciu unii brzeskiej te same cerkwie stały się świątyniami nowego wyznania, z czasem nazwanego greckokatolickim. Wzrost ukrainizacji tego obrządku doprowadził w okresie międzywojennym do konfliktów narodowo-wyznaniowych wśród Łemków i do powrotu części z nich do praktykowanego przez przodków prawosławia. Jedną z najboleśniejszych konsekwencji wysiedlenia Łemków w latach 40. XX w. było pozostawienie cerkwi, stanowiących stały element krajobrazu rodzinnych miejscowości, z charakterystyczną architekturą i ikonostasem. Przestały one być budynkami użyteczności publicznej, stały się symbolem duchowej więzi z utraconą małą ojczyzną. Opuszczone, ulega- 
ły dewastacji lub były przejmowane przez struktury Kościoła rzymskokatolickiego i dostosowywane do potrzeb innego wyznania.

Po kilkunastu latach dla powracających w Beskidy Łemków spór o odzyskanie dawnej świątyni był jednym z najboleśniejszych doświadczeń, a sprawa użytkowania budynków cerkiewnych nadal pozostaje głównym czynnikiem konfliktogennym na Łemkowszczyźnie. Kwestia własności cerkwi to dla Łemków problem o charakterze nie tylko religijnym, lecz również narodowym i osobistym. $Z$ użytkowaniem dawnych świątyń łemkowskich przez księży rzymskokatolickich, odprawiających nabożeństwa według obrządku łacińskiego, trudno jest się pogodzić zarówno grekokatolikom, jak i prawosławnym.

Burzliwe dzieje polityczne ostatnich kilkudziesięciu lat, a zwłaszcza wysiedlenia Łemków i polityczno-administracyjne decyzje władz PRL, całkowicie przekształciły zarówno strukturę wyznaniową, jak i krajobraz kulturowy Łemkowszczyzny. Istotny wzrost wśród Łemków wyznawców prawosławia oraz rzymskiego katolicyzmu był spowodowany prawie wyłącznie czynnikami politycznymi. Z punktu widzenia ochrony unikatowego dziedzictwa kulturowego Beskidów najtragiczniejsze jest bezpowrotne zniszczenie kilkudziesięciu zabytkowych budynków cerkiewnych, wielu kapliczek i cmentarzy. Ponadto większość ocalałych świątyń uległa daleko posuniętej, celowej latynizacji. Pod względem wyznaniowym tzw. dawna Łemkowszczyzna już nie istnieje. Wśród mieszkańców zdecydowanie dominują wyznawcy katolicyzmu w obrządku łacińskim, także większość dawnych cerkwi jest od kilkudziesięciu lat własnością Kościoła rzymskokatolickiego.

Kolejne zmiany polityczne, społeczne i gospodarcze ostatnich trzech dekad, zwłaszcza demokratyzacja życia politycznego, unormowanie sytuacji Kościoła greckokatolickiego oraz akcesja Polski do Unii Europejskiej, dają nadzieję na poprawę sytuacji, przede wszystkim konserwatorskiej i materialnej, ocalałych cerkwi. Nie zlikwidowały one następstw polityki władz komunistycznych (wysiedleń, rozbiórki cerkwi, zmian struktury wyznaniowej mieszkańców oraz własnościowej cerkwi), ale umożliwiły realną ochronę łemkowskiego dziedzictwa kulturowego i religijnego oraz częściową odbudowę struktur Kościoła greckokatolickiego w Beskidach. Pozyskiwanie środków europejskich na renowację świątyń, rozbudowa tras turystycznych i aktywizacja lokalnych społeczności pozwalają przypuszczać, że trwające przez kilkadziesiąt lat niszczenie i dewastacja sakralnej architektury Łemkowszczyzny dobiegły końca. 


\section{Literatura}

Barwiński M., 1999, Współczesna tożsamość etniczna i kulturowa Łemków na obszarze Łemkowszczyzny - uwarunkowania $i$ konsekwencje, „Acta Universitatis Lodziensis. Folia Geographica Socio-Oeconomica", 2, s. 53-69.

Barwiński M., 2013, Geograficzno-polityczne uwarunkowania sytuacji Ukrainców, Eemków, Białorusinów i Litwinów w Polsce po 1944 roku, Lódź.

Budzyński Z., 1992, Struktura terytorialna i stan wiernych Kościoła unickiego na Łemkowszczyźnie w XVIII wieku, [w:] Czajkowski J. (red.), Łemkowie w historii i kulturze Karpat, cz. 1, Rzeszów, s. 267-284.

Czajkowski J., 1992, Dzieje osadnictwa historycznego na Podkarpaciu i jego odzwierciedlenie w grupach etnicznych, [w:] Czajkowski J. (red.), Łemkowie w historii i kulturze Karpat, cz. 1, Rzeszów, s. 27-167.

Drozd R., 2010, Ukraińcy (do 1989 r.), [w:] Dudra S., Nitschke B. (red.), Mniejszości narodowe i etniczne w Polsce po II wojnie światowej. Wybrane elementy polityki państwa, Kraków, s. 91-112.

Drozd R., 2015, Losy cerkwi greckokatolickich i prawosławnych w Polsce w latach 19441989, [w:] Halczak B. i in. (red.), Łemkowie, Bojkowie, Rusini - historia, wspótczesność, kultura materialna i duchowa, t. 5, Słupsk-Zielona Góra-Svidnik, s. 409-420.

Drozd R., Halczak B., 2010, Dzieje Ukraińców w Polsce w latach 1921-1989, Warszawa.

Dudra S., 2004, Kościól prawosławny na ziemiach zachodnich i pótnocnych Polski po II wojnie światowej, Zielona Góra.

Dudra S., 2014, Odbudowa prawosławnej sieci parafialnej na Łemkowszczyźnie po 1956 roku jako element wielokulturowości regionu, ,Studia z Geografii Politycznej i Historycznej", 3, s. 307-320.

Halczak B., 2015, Dzieje Łemków od średniowiecza do współczesności, Warszawa.

Horbal B., 2010, Lemko studies: A handbook, New York.

Keller J., 1982, Prawostawie, Warszawa.

Krochmal A., 1992, Stosunki między grekokatolikami i prawosławnymi na Łemkowszczyźnie w latach 1918-1939, [w:] Czajkowski J. (red.), Łemkowie w historii i kulturze Karpat, cz. 1, Rzeszów, s. 285-299.

Michna E., 2004, Kwestie etniczno-narodowościowe na pograniczu słowiańszczyzny wschodniej i zachodniej. Ruch rusiński na Słowacji, Ukrainie i w Polsce, Kraków.

Moklak J., 2007, Fenomen tożsamości Łemków - uwarunkowania historyczne (do 1945 r.), [w:] Dudra S. i in. (red.), Łemkowie, Bojkowie, Rusini-historia, wspótczesność, kultura materialna i duchowa, t. 1, Legnica-Zielona Góra, s. 79-88.

Nowakowski K., 1992, Sytuacja polityczna na Łemkowszczyźnie w latach 1918-1939, [w:] Czajkowski J. (red.), Łemkowie w historii i kulturze Karpat, cz. 1, Rzeszów, s. 313351. 
Pactwa B., 1992, Próby reintegracji społeczności Łemków w Beskidzie Niskim, [w:] Dziewierski M., Pactwa B., Siewierski B. (red.), Dylematy tożsamości. Studium społeczności łemkowskiej w Polsce, Katowice, s. 92-138.

Prach B., 1992, Apostolska Administracja Łemkowszczyzny, [w:] Czajkowski J. (red.), Łemkowie w historii i kulturze Karpat, Rzeszów, cz. 1, s. 299-312.

Pudło K., 1992, Dzieje Łemków po drugiej wojnie światowej (zarys problematyki), [w:] Czajkowski J. (red.), Łemkowie w historii i kulturze Karpat, cz. 1, Rzeszów, s. 351381.

Reinfuss R., 1990, Śladami Łemków, Warszawa.

Wojewoda Z., 1994, Zarys historii Kościoła greckokatolickiego w Polsce w latach 19441989, Kraków.

Wysocki J., 2011, Ukraińcy na Lubelszczyźnie w latach 1944-1989, Lublin.

\section{Political meanders of the Lemko churches}

Summary

The Lemko churches preserved to present times are one of the most characteristic elements of the cultural landscape of the northern Carpathians. They are also clear, visual evidence of the multinational and multi-confessional history of the Beskidy mountains. Both - dramatic and complicated history and contemporary situation of the Lemko minority, perfectly presents direct impact of political events on the history of the Lemkos and their spiritual and material culture.

The main purpose of the article is to show, on the example of the Lemko region, the overriding influence of political conditions on the denominational structure. Transformations and political decisions made without the participation of the most interested, in this case the Lemkos, effectively determined the private sphere of life like a religious faith. It took place both in the twentieth century and also few hundred years earlier. It also takes place today.

Keywords: Lemko, Lemko region, religious structure, Orthodoxy, Greek Catholic Church, cultural heritage.

Dr hab. Marek Barwiński, prof. UŁ

Uniwersytet Łódzki

Wydział Nauk Geograficznych

Katedra Geografii Politycznej, Historycznej i Studiów Regionalnych

90-142 Łódź, ul. Kopcińskiego 31

e-mail: marek.barwinski@geo.uni.lodz.pl 